NBER WORKING PAPER SERIES

ECONOMIC EVENTS AND KEYNESIAN IDEAS:

THE 1930S AND THE 1970s

Michae1 R. Darby

James R. Lothian

Working Paper No. 1987

NATIONAL BUREAU OF ECONOMIC RESEARCH

1050 Massachusetts Avenue

Cambridge, MA 02138

July 1986

Forthcoming in: For Fifty Years on: The Relevance and Irrelevance of Keynes' General Theory to Modern Times edited by John Burton. The research reported here is part of the NBER's research program in International studies. Any opinions expressed are those of the authors and not those of the National Bureau of Economic Research. 


\title{
Economic Events and Keynesian Ideas: \\ The 1930s and the 1970s
}

\begin{abstract}
Keynes' General Theory was a brilliant attempt to explain the paradox of low interest rates, ineffectual easy monetary policy, and low investment during the Great Depression. We argue that Keynes! failure to distinguish between low nominal and high real interest rates led him to misinterpret a tight and all too effective monetary policy and unnecessarily hypothesize a dowsward shift in investment demand. Keynesian ideas in turn profoundly influenced econamic policy in the 1960s and 1970s. The resulting postwar inflation - rather than scholarship on what actually happened in the 1930s -- appears to be the primary reason for the waning influence of the ideas derived from the General Theory.
\end{abstract}

Michae 1 R. Darby Department of Economics University of California Los Angeles, CA 90024
James R. Lothian Citicorp Investment Bank 55 water Street - 42nd Floor New York, NY 10043 
Like the proverbial chicken and the egg, economic events and macroeconomic theory have borne an ongoing ambiguous relationship to one another. Keynes himself, in his scathing indictment of the influence of "academic scribblers" on actual policy, pointed to one such avenue of impact. I George stigler in his Nobel lecture "The Process and Progress of Economics" pointed to a channel leading in the exact opposite direction. singling out macroeconomics as "notorious" for "its responsiveness to contemporary events," stigler cited the unemployment of the 1930 s as the reason for the success of Keynes' General Theory and the inflation of the 1970 s as the reason for its demise. 2

This paper explores and develops stigler's hypothesis: We first examine the economic experience of both the United States and the United Kingdom during the interwar years, contrasting Keynes' perceptions of those events with the findings of subsequent empirical research. We then turn to the growing influence of Keynesian ideas on economic policy in the 1960s and 1970s, the international transmission of that influence through the Bretton Woods system, and the resultant discrediting of those ideas.

\section{The Inter-War Years}

To most American observers, the Great Depression seemed to defy explanation. Its extraordinary severity, substantial duration, and almost world-wide scope, combined to give it the aura of an entirely new species of economic animal. Reinforcing this view for many British observers, no doubt, was experience in the previous decade.

The Macmillan Report, published in 1931, described the 1920s in Britain as a period of "abnormal industrial depression and extensive unemployment." 3 other accounts paint an equally bleak picture of 
those years, from Orwell's classic narrative, The Road to wigan Pier, to the more workaday annual summaries of the Economist. And even though more recent analyses of movements in aggregate income place the decade in a somewhat better light, it was by no means an ordinary period.

From the beginning of 1920 to the end of 1929, there were three full cyclical contractions and the start of a fourth, the Great Depression -- an historical record. 4 Moreover, these four contractions, taken in toto, added up to seven years of business decline in the thirteen years ending in 1932 -- another historical first. Unemployment throughout this period ran continually high, an average rate for the years 1921 to 1929 of 9.18, with a peak in 1921 of 12.28 , a decrease of close to 5 percentage points between then and 1927 and finally a spike to a record 178 in 1932.

In the United States the twenties, though also beginning with a severe business downturn in 1920-21, were a period of strong real growth and low average unemployment. Not until 1929 did things turn sour, but then they turned sour indeed. When the Great Depression ended in the United States in 1933, real income was nearly 458 below its 1929 level and the level of unemployment stood at 20.68.

Pre-Keynesian monetary theory had two major concerns. One, the long-run relationship between money and the price level -- the "neutrality" of money -- is well known. The other, though very often overlooked, was no less central. It is the question of the dynamic process by which monetary disturbances were transmitted to prices, output and employment in the shorter run. Figuring prominently in the expositions of eighteenth and early nineteenth century British 
writers such as David Hume and Henry Thornton, this question received its fullest treatment prior to the rebirth of quantity theory in the latter half of this century in the work of the American economist Irving Fisher who in 1926 undertook a statistical study of U.S. cyclical fluctuations the like of which did not become common in the literature until 40 years later. 5

This developed schema of analysis, however, was abandoned -particularly in Cambridge -- with little more than nod to the empirical evidence. Assertions by officials of the Federal Reserve system in the United states and of the central banks of other countries that monetary policy was loose but ineffectual and the low financial market interest rates of the Depression years appear to have been the only evidence taken into account. 6

Keynes' General Theory can be seen as his explanation of why monetary ease did not work and what -- if not money -- caused the Great Depression. Fisher had proclaimed the business cycle "a dance of the dollar". Keynes declared it a dance of investment. 7

With both real government spending and real consumer spending relatively stable in magnitude over the course of the trade cycle, investment is the component of aggregate real income that accounts for most of its cyclical variation. The pre-Keynesian monetary theory we have just reviewed and the modern quantity theory explain this cyclical variation in investment as a movement along a stable demand function in which expectations play a crucial but predictable (endogenous) role in the transmission of (predominantly) monetary disturbances. Keynes expected lower interest rates to increase investment in the Depression. When the increase did not occur, he concluded that an overwhelming shift in the demand curve itself must 
have taken place.

The conclusion, however, did not follow. Underlying it was a confusion between Fisher's (and Thornton's) distinction between nominal and real rates of interest. Real investment is a function of real rates of interest, not of nominal rates. The latter were certainly low in the Depression but price levels in both America and Britain were falling. Real interest rates, the difference between nominal rates and the rates of inflation that investors anticipate will prevail over the lives of the particular instruments, must almost certainly have been high.

This failure to distinguish between nominal and real interest rates also led Keynes to accept the characterization of monetary policy as loose but ineffective. ${ }^{8}$ Keynes rationalized this alleged ineffectiveness of monetary policy by the notion of a liquidity trap. At low levels of interest rates, Keynes hypothesized, money and bonds would be near-perfect substitutes. An open market purchase, therefore, would simply give rise to a substitution of bonds for money. Nothing else would happen. Monetary policy under these circumstances would be impotent.

Keynes explicitly stated that this liquidity trap was a limiting case -- one that was not known ever to have occurred in practice. 9 Nevertheless, he went on to treat it as true to a first approximation. The economic variables in his model Keynes defined in terms of wage units. Given Keynes' related assumption of a fairly stable ratio between the level of product prices and the level of wages, the overall price level, which in the classical quantity theory analysis was the outcome of the interaction between the supply of and the demand for money, was implicitly held constant. 
This set of assumptions, as it has turned out, was untenable -the "facts" of the situation that Keynes apparently took as a given were not facts at all. One of the major contributions of Milton Friedman's and Anna J. Schwartz's (1963) A Monetary History of the United States, 1867-1960 was to explode forever this myth of an expansionary yet ineffective monetary policy in the United states. Their data show that the supply of money in the United states in the 1930's far from increasing, fell by an unprecedented amount, slightly over $40 \%$ between 1929 and 1933. The only other period during in which a near-similar decline in the U.S. money stock has been recorded was $1839-43$, when M2 fell by close to $28 \% .10$ This, too, was called a "great depression".

The reason that the Great Depression of the 1930 s was so severe, Friedman and schwartz concluded, was that monetary policy in the United states was so inept. Confronted by a series of bank failures that were causing substantial declines in the stock of money, the Federal Reserve took virtually no offsetting actions. Their own monetary liabilities -- high-powered money or the monetary base -actually declined by 38 between 1921 and 1930 and from 1930 until 1932 rose by only a little over 10\%. This passivity came in a time of banking panics and resultant frantic scrambles for currency by money holders and for reserves by banks. It was as if the history of the Bank of England's actions in times of financial crisis in the nineteenth century had never been known and Bagehot had never written.

Analyses subsequent to that of Friedman and Schwartz have only served to buttress their conclusions. Investigations of money demand behavior have uncovered no evidence of a liquidity trap in either the 
aggregate time series data or the richer cross-state data for the United states. 11 other studies have shown that given the greater decline" in money supply in the Depression the decline in U.S. nominal income was in line with historical experience during other cyclical contractions. ${ }^{12}$ In a similar vein, Darby and Michael Melvin (1986, pp. 374-384), like Clark Warburton much earlier (1951), emphasize the substantial reduction in money growth beginning in April 1928, long before the summer 1929 downturn in business activity, as a result of a conscious restrictive decision of the Federal Reserve system.

A related argument, that money supply in the Depression was purely passive, responding to rather than exerting an independent influence on real output, has also been shown to be of dubious validity. Two studies examining the data for other contractionary episodes in both the United States and the United Kingdom have concluded that banking panics -- the mechanism by which such induced changes in money supply supposedly occurred -- were not primarily a response to the cycle. ${ }^{13}$ These studies show further that a strong association between financial panics and substantial cyclical contractions only exists when the fluctuations in money supply were themselves substantial.

A final body of evidence is provided by international comparisons. Countries like Spain and China that were not on the gold standard and, hence, were immune to the direct monetary effects of the U.S. money supply decline escaped the full force of the Depression. 14 Those that were on the gold standard did not. similarly, and we turn to some of this evidence immediately below, countries that left the gold standard earliest recovered the quickest. 
Particularly illustrative is the interwar experience of the United Kingdom. ${ }^{15}$. In the United kingdom year-to-year, money supply growth declined from 2.18 in 1928 to .68 in 1929 and continued at roughly the same pace in 1930 before turning slightly negative in 1931. Then, after the abandonment of gold in 1931, money supply again began to grow, increasing at a 3.58 per year average rate over the next two years. Real income between 1929 and 1931 fell by nearly 8.08. At that point the recovery began, slowly at first but by 1932 gathering momentum.

In the United States during these years, money supply declined much more sharply and for a longer period than in the United kingdom. The average decrease was 18 per annum from April 1928 to April 1930, 58 during the next 12 months, $20 \%$ from April 1931 to April 1932, and 17.58 during the next 12 months, at which time money supply growth resumed. Both real income and industrial production fell precipitously -- real income by close to 358 from 1929 to 1932 and Industrial production by over 60\%. Real Income in the United States, moreover, continued to fall through 1933 and, unlike the United Kingdom, failed to reach its 1929 level until almost the end of the decade.

From a cyclical standpoint, this was an exact reversal of roles from those that the two countries played in the previous common severe interwar contraction of 1920-21. What makes this juxtaposition particularly interesting, with regard both to the Great Depression itself and to the experience of the United Kingdom in the 1920s, is that the two countries' monetary roles were also reversed. In both countries, money supply growth had averaged somewhat over $12 \%$ per year from 1914 until 1920. In the United States, it turned 
negative in 1921, then picked up substantially during the next two years and in the process more than cancelled the 1920-21 decline in the stock of money. In the United kingdom, a monetary reversal of this sort did not take place. The money supply actually continued to decline between 1921 and 1923 after growing by less than 18 in 1921. The reason for the disparity in monetary behavior in the two countries was the desire of the British government to return to the gold standard at the 1914 parity.

The real sicies of the two economies reacted as might be expected. ${ }^{16}$ Real income and industrial production in 1921 fell in each by substantial amounts. But in the United states -- the country with the post-contraction expansion in money -- both measures of real activity picked up much more rapidly and thus made up their initial declines much sooner than in the United Kingdom.

Keynes' General Theory, therefore, was written to explain perceived empirical paradoxes which did not exist. Contrary to contemporaneous impressions, monetary disturbances were of appropriate magnitude and timing to explain both the general pattern and much -- though certainly not all -- of the important details of the inter-war cyclical movements in America and Britain. Focussing on nominal interest rates, Keynes misdiagnosed the thrust of monetary policy and entirely missed the channel from low money growth to high real interest rates to a low quantity of investment demanded.

\section{The Post-WWII Inflation}

If Keynes' model obfuscated rather than illuminated the Great Depression, its application to policy during our own era has had even more deleterious effects. One can debate the extent to which 
economic 1deas have consequence -- whether they do in fact exert a strong independent influence on official policy or whether they merely provide rationalizations for government officials to pursue the policies they deem expedient and would have pursued in any case. But one thing is clear, the inflationary policies followed in both the United Kingdom and the United states for much of the postwar period would not have commanded the intellectual respect that they did were it not for The General Theory and the later theorizing in the same vein that it engendered.

In the model of The General Theory the price level was constant. Money, therefore, was precluded from having any inflationary impact. In later versions of the model, it had no impact so long as the economy was below the level of full employment. Underlying the implementation of both sets of models, moreover, was a belief in full employment as a desideratum and a stress on the manipulation of financial market interest rates as the means to achieve that goal.

The consequences of this line of reasoning were predictable and in broad outline were predicted well before the fact. Inflation, said the critics of such models, would eventually rise and in one sophisticated analysis of the problem would most likely end up rising at faster and faster rates. 17

This is, of course, what happened. In the United Kingdom, inflation started on its upward trend earlier than in the United states and ultimately reached higher peaks. Nevertheless, the basic process was the same.

Money supply growth increased and inflation rose. At some juncture, the economy went into recession, whether because the monetary authorities tightened to counteract the inflation, some 
other factors intruded, or both. For a time thereafter inflation temporally abated.

Confronted with the now lower inflation and the higher unemployment, the monetary authorities shifted gears back to expansion and thus set the next round of the process into motion. In this round, though, policy had to become more expansive than in the early stages of the previous one. The reason is that economic participants caught on to what was happening. They adjusted their expectations with regard to inflation and hence ultimately policy. The policy stimulus to nominal spending and income had to be greater to continue to affect real ircome and not simply go into higher prices. Inflation thus was put on an accelerating track. Inflation in the United Kingdom, in the last half of the $1950 \mathrm{~s}$ averaged 2.18 per year. ${ }^{18}$ By the first half of the '60s it had risen to an average annual rate of $3.6 \%$. In the United states during the late '50s and early '60s, in contrast, inflation was still low -- an average of $1.6 \%$ per year between 1955 and 1965 . By the end of the decade, however, it had reached a peak of 5.28 and, although falling somewhat in the aftermath of the 1969-70 recession was soon to be headed higher. In the United kingdom inflation continued to run a cycle ahead of the rate in the United States, moving up sharply to a peak of close to 98 in 1971, before dropping back slightly a year later.

During this period, moreover, inflation became worldwide. Prices in other industrial countries followed much the same course, with only the absolute levels of inflation rates but not their tendency to drift upwards differing among countries. 
At the time, the popular view among economists writing in the Keynesian tradition was that the inflation was the result of outside forces, special factors. Initially, increased militancy of trade unions and spreading monopoly power of the business sector were the two most often cited. Then in the early 1970s, when prices of agricultural products and other raw materials began to soar, proponents of this general class of explanations keyed in on these increases as the specific factors driving inflation. The oil-price shocks of the early and late 1970 s and the further increases in inflation in the United Kingdom and in the United states that came in their wakes only served to confirm those beliefs.

The argument -- except by pure serendipity -- does not explain the ability of economists who viewed the world in pre-keynesian quantity-theory terms to project the drift of inflation during these years well before the fact. More important, it runs counter to the bulk of the empirical evidence amassed afterwards. Our own research on inflation in the United States, the United Kingdom and six other major industrial countries is a prime example. ${ }^{19}$ The results of that study are fully consistent with the quantity-theory view.

The major factor accounting for the world inflation through the early 1970s, we found, was the upward trend in American monetary growth. Through a variety of channels operable under fixed exchange rates, the expansionary policy in the United States spilled over abroad, leading to increases in monetary growth and subsequently in inflation too. Some countries, like Germany, appear to have been unwilling participants in the process. Others like the United Kingdom apparently would have pursued expansionary policies on their own. Indeed, this divergence in goals between the United states and 
other countries was the major reason that the Bretton woods system of fixed exchange rates broke down. Oil prices in the early 1970s, we found, played a limited role.

During the late 1970 s the same thing also appears to have been true. Most countries did experience a more or less similar increase in inflation following the second oil-price shock in 1979.20 But these fluctuations in inflation rates in the various countries were about markedly different average rates of inflation for the period as a whole. These average rates of inflation, in turn, bore a striking correspondence to the degree of policy expansiveness under the floating exchange rate system then in existence. Countries that engineered a decrease in their trend rates of monetary growth rates during the floating-rate period relative to the fixed-rate period on average saw a near one-to-one decrease in their trend rates of inflation. Countries that, in contrast, engineered an increase in monetary growth on average saw a near one-to-one increase in trend inflation. 21 oil price increases, therefore, either generated these changes in trend monetary growth rates in the various countries, which seems implausible given the differences in their monetary institutions and in their policy goals, or had little substantial lasting effects.

\section{Conclusions}

Keynes' General Theory was a brilliant explanation of fundamentally misappreciated events. Subsequent research has found evidence neither of the loose but ineffective monetary policy in the Depression nor of the substantial downward shift in the investment function in that episode that were central to the message of The 
General Theory. Appearances to the contrary seem to have been rooted in a major confusion between nominal and real interest rates. Had Keynes" thinking incorporated this distinction, the events of the Depression would have seemed much less paradoxical and The General Theory might never have been written.

Discrediting as later scholarship has been to Keynes' analysis, it is the events of the past two decades that have proven most damning. Keynes' theories were applied, but found extremely wanting. The post war inflation stands as their monument, a monument to an ingenuous structure based upon a nearly total misinterpretation of what actually happened slightly more than half a century ago. 


\section{REFERENCES}

Benjamin, Daniel K., and Levis A. Kochin, "Searching for an Explanation of Unemployment in Interwar Britain," Journal of Political Economy, June 1979, 87: 441-478.

Burns, Arthur F., and Wesley C. Mitchell, Measuring Business Cycles, New York: NBER, 1946.

Cagan, Phillip, Determinants and Effects of Changes in the stock of Money 1875-1960, New York: Columbia University Press for NBER, 1965.

Choudhri, Ehsan U., and Levis A. Kochin, "The Exchange Rate and the International Transmission of Business Cycle Disturbances: Some Evidence from the Great Depression", Journal of Money, credit and Banking, November 1980, 12: 565-74.

Committee on Finance and Industry, Report [the Macmillan Report], Cinnd.389, London: HMSO, 1931

Darby, Michael R., "Three-and-a-Half-Million U.S. Employees Have Been Mislaid; or, An Explanation of Unemployment, 1934-1941," Journal of Political Economy, February 1976, 84: 1-16.

Darby, Michael R., James R. Lothian and Arthur E. Gandolfi, Anna J. Schwartz and Alan C. Stockman, The International Transmission of Inflation, Chicago: University of Chicago Press for NBER, 1983.

Darby, Michael R.: and Michael T. Melvin, Intermediate Macroeconomics, Glenview, Ill.: Scott, Foresman and Co., 1986.

The Economist, various issues, 1921-1929.

Feinstein, C.H., National Income Expenditures and output of the United Kingdom, 1855-1965, Cambridge: Cambridge University Press, 1972 .

Fisher, Irving, "A Statistical Relation between Unemployment and Price Changes," International Labor Review, June 1926, 13: 785-792. (Reprinted Journal of Political Economy, March/April 1973, 81: 496-502.)

"Are Booms and Depressions Transmitted Internationally Through Monetary Standards?," Bulletin of the International statistical Institute, 1935, 28: 1-29.

Friedman, Milton, "The Role of Monetary Policy," American Economic Review, March 1968, 58: 1-17.

Friedman, Milton and Anna J. Schwartz, Monetary History of the United States, 1867-1960, Princeton: Princeton University Press for NBER, 1963. 
Monetary Trends in the United States and the United Kingdom, Chicago: University of Chicago Press for NBER, 1982 .

Gandolfi, Arthur E., "Stability of the Demand for Money during the Great Contraction -- 1929-1933," Journal of Political Economy, September/October 1974, 82: 969-83.

Gandolfi, Arthur E., and James R. Lothian, "Did Monetary Forces Cause the Great Depression? A Review Essay," Journal of Money Credit and Banking, November 1977, 9, 679-91.

the Present," "The Demand for Money from the Great Depression to
thean Economic Review, May 1976, 66: 46-51.

Huffman, Wallace E. and James R. Lothian, "The Gold Standard and the Transmission of Business Cycles, 1833-1932," in Michael D. Bordo and Anna J. Schwartz, eds., Retrospective on the Classical Gold Standard, 1821-1931, Chicago: University of chicago Press for the NBER, 1984 .

Hume, David, "Of Money" [1752], reprinted in Eugene Rotwein, ed., David Hume Writings on Economics, Madison: University of Wisconsin Press, 1970, 33-46.

International Monetary Fund, International Financial statistics, various issues.

Keynes, John Maynard, The General Theory of Employment Interest and Money, London: Macmillan, 1967.

Lothian, James R., "Comments on 'Monetarist Interpretations of the Great Depression'," in Karl Brunner ed., The Great Depression Revisited, Boston: Martinus Nijhoff Publishing for Rochester Studies in Economics and Policy Issues, 1981, 134-147.

, "Equilibrium Relationships Between Money and other Economic Variables" American Economic Review, September 1985, $7.5,828-835$.

Meltzer, Allan M., "The Demand for Money: The Evidence from the Time Series," Journal of Political Economy, June 1963, 71, 219-246.

Nobay, A. Robert, and Harry G. Johnson, "Monetarism: A HistoricTheoretic Perspective," Journal of Economic Literature, June 1977, 15: $470-485$.

orwell, George, The Road To Wigan Pier, London: Victor Gollanez Ltd. , 1937.

Schwartz, Anna J., "Understanding 1929-1933", in Karl Brunner ed., The Great Depression Revisited, Boston: Martinus Nijhoff Publishing for Rochester Studies in Economics and Policy Issues, 1981. 
Stigler, George, "Nobel Lecture: The Process and Progress of Economics" Journal of Political Economy, August 1983, 91: 529-545.

Temin, Peter, Did Monetary Forces Cause the Great Depression?, New York: Norton, 1976.

Thornton, Henry, An Enquiry into the Nature and Effects of the Paper Credit of Great Britain [1802], reprinted with additional material in F.A. von Hayek, ed., London: Allen and Unwin, 1939.

United states Department of Commerce, Bureau of Economic Analysis, Long-Term Economic Growth, 1860-1970, Washington D.C.: Government Printing Office, 1973.

Warburton, Clark, "The Misplaced Emphasis in Contemporary Business-Fluctuation Theory," in Friedrich A. Lutz and Lloyd W. Mints, eds. Readings in Monetary Theory, Homewood, Ill.: Richard D. Irwin, Inc., for the American Economic Association 1951. [An expanded reprint of his article in the Journal of Business, 1946, 19: 199-220.] 
NOTES

1

The General Theory, pp. 383-384.

2

Journal of Political Economy, August 1983, 91, p. 534.

3

Committee on Finance and Industry, Report, p. 6 .

4 Sources of the interwar data reported here and below were as follows: reference cycle dates, Arthur F. Burns and Wesley C. Mitchell (1946); real income (net national product) for both countries and yearly U.K. money supply (M2), Milton Friedman and Anna J. Schwartz (1982); U.K. industrial production and unemployment (as a percent of total employees), C.H. Feinstein (1972); monthly U.S. money supply (M2) and the monetary base (high-powered money), Friedman and Schwartz (1963); U.S. industrial production, U.S. Department of Commerce (1973); U.S. unemployment, Darby (1976). Note that all percentage changes referred to below were computed on a continuously compounded basis.

5

Fisher investigated the effects of changes in the price level on output using an empirically based version of the modern Lucas supply function.

The early pre-Keynesian analysis is typified by David Hume "of Money" [1752], reprinted in Eugene Rotwein, ed. "David Hume Writings on Economics (1970) and Henry Thornton; An Encuiry into the Nature and Effects of the Paper Credit of Great Britain [1802], F.A. von Hayek, ed. (1965).

A. Robert Nobay and Harry G. Johnson (1977, pp. 471-476) have an excellent discussion of the thrust of pre-Keynesian monetary theory and its emphasis on the dynamics of the "transition period."

6

Clark Warburton (195I) details the apparent ignorance of an astonishingly large number of prominent economists of the period to the factual evidence on money supply changes in the 1920 s and 1930 s. (See, especially, his note lo).

7 This characterization is taken from a lecture by Milton Friedman.

8 This same confusion is present in Peter Temin's (1976) attempt to resuscitate Keynes' explanation of the Depression. See Arthur $\mathrm{E}$. Gandolfi and James R. Lothian (1977) for a further critique of Temin's analysis.

9

The General Theory p. 207.

10

The figures cited are from Wallace E. Huffman and Lothian (1984).

11 Gandolfi, (1974) and Gandolfi and Lothian (1976) contain estimates of money demand functions from cross-state data. Meltzer (1963) and Friedman and schwartz (1982) provide estimates from time series data for the United States and for the United states and the United Kingdom, respectively. None of these studies shows a liquidity trap to be characteristic of the data. 
12

See Lothian (1981) for estimates of one such relationship. Also see the discussion in Schwartz (1982).

13 Phillip Cagan (1965) analyzes the relationships among cyclical contractions, monetary contractions and financial crisis for the United states during the late nineteenth and early twentieth centuries. Huffman and Lothian (1984) make comparisons similar to Cagan's using data for both the United Kingdom and the United states for the period beginning in 1833 and ending with the Great Depression of the 1930s.

14 Experiences of non-gold standard countries and of countries that left the gold standard are analyzed by Ehsan Choudhri and Levis Kochin (1980). Also see Irving Fisher (1936) for an earlier, and in many respects similar, analysis.

15 This discussion draws on Lothian (1982), pp. 142 to 145.

16 This painful process of slow monetary growth that began in 1921 and continued throughout the 1920s in the United Kingdom is one factor responsible for the high unemployment. Daniel Benjamin and Levis Kochin (1979) provide evidence of another: unemployment benefits were substantially raised in real terms, which by their calculations, increased the normal (non-cyclical) level of unemployment 2 to 3 percentage points.

17 The forecast of accelerating inflation is contained in Friedman's (1969) American Economic Association Presidential Address.

18 The source of post-World War II data cited here and below is the International Monetary Fund's International Financial statistics.

19 Darby, Lothian, et al, The International Transmission of Inflation. The other six countries analyzed in that study were Canada, France, Germany, Italy, Japan and the Netherlands.

20 The increase in annual inflation rates in the same eight countries covered in our International Transmission study averaged $4.9 \%$ percentage points between 1978 and 1980 - the years surrounding the second oil-price shocks. Average rates of inflation in the period 1976 to 1980, however, differed substantially among these countries. Japan and Germany, the two countries with the least expansive monetary policy experienced relatively low average rates of inflation - an average of 5.3\% per year for the two combined. France, Italy and the United Kingdom, the countries with the most expansive policy, experienced the highest rates -- an average of $15.4 \%$ per year for Italy and the United Kingdom combined and 10.4\% per year in France. The other three countries Canada, the Netherlands and the United states fell somewhere in between in terms of both policy expansiveness and inflation.

21 see Lothian (1985) for an analysis of the relationship between changes in average money supply growth rates and in average inflation rates in 20 OECD countries over the periods 1956 to 1973 and 1974 to 1980. 
Michael R. Darby was born in 1945 in Dallas, Texas, and educated at Dartmouth College (A.B. 1967) and the University of Chicago (M.A. 1968, Ph. D. 1970). In 1972 Darby joined the economics faculty of the University of California, Los Angeles, where he is now Professor of Economics, after a two-year stint as assistant professor at the Ohio state University. He has had visiting appointments at the National Bureau of Economic Research, of which he currently is a Research Associate, and the Hoover Institution at stanford University. He serves as Editor of the Journal of International Money and Finance and on the Editorial Board of the American Economic Review. He is the author or coauthor of seven books and monographs and of numerous professional articles on macroeconomics and international finance. His leisure interests include art and naval history, music, and swimming. 


\section{James R. Lothian}

Více President and Economist with Citicorp Investment Bank since 1983, Lothian joined Citibank in 1972, receiving his doctorate in economics from the University of Chicago a year later. He has been a Research Associate of the National Bureau of Economic Research, is a member of the editorial board of the Journal of International Money and Finance and has held teaching positions at Queens college of the City of New York, the University of Illinois in Chicago and Lake Forest College. He is coauthor of the International Transmission of Inflation, has published in numerous scholarly journals and collections and has written regularly on financial and economic topics for the business press and for business periodicals. At Citicorp he is author and editor of Economics and Markets, a regular series of monographs on current economic and financial topics. 